\title{
Prilog poznavanju mramorne altaristike i skulpture 18. stoljeća u trećoredskim crkvama na Krku i Cresu
}

\begin{abstract}
U 18. stoljeću obnavljaju se i novim inventarom popunjavaju samostanske crkve franjevaca trećoredaca na Krku i Cresu. Najraniji mramorni oltar koji je podignut jest onaj posvećen svetom Antunu Padovanskom u crkvi svetog Franje u Krku. Sagradio ga je arhitekt Giuseppe Cavallieri 1708., no o majstoru se gotovo ništa ne zna. Stilskom se analizom ovdje kontekstualizira Cavallierijev oltar te se njegovoj radionici pripisuje petnaestak oltara u Istri i na Krku, nastalih u prvim dvama desetljećima 18. stoljeća. U drugoj četvrtini 18. stoljeća gradi se glavni te bočni oltar posvećen svetom Nikoli u crkvi svete Marije Magdalene u Portu. To je djelo radionice riječkog altarista i kipara Antonija Michelazzija te kipara suradnika. Za glavni oltar u Martinšćici nastaje malena, ali vrlo kvalitetna skulptura svetog Jerolima kojoj je ovdje prepoznat predložak u slavnom venecijanskom kipu Alessandra Vittorije iz 16. stoljeća. Konačno, analizira se neobjavljeni glavni oltar u crkvi svetog Nikole u Porozini, jedinstven po svojoj tipologiji s trima mramornim skulpturama izvedenima 1747. godine.
\end{abstract}

Na otocima Krku i Cresu od 15. stoljeća djelovalo je nekoliko samostana franjevaca trećoredaca. $\mathrm{Na}$ otoku Cresu bili su to samostani svetog Jeronima u Martinšćici te svetog Nikole u Porozini. Na susjednom Krku samostan svete Marije u Glavotoku, potom onaj svete Marije Magdalene u Portu, a od druge polovine 18. stoljeća i samostan svetog Franje u gradu Krku. O umjetničkom inventaru spomenutih samostanskih crkava malo se pisalo, a o njihovim mramornim oltarima i skulpturi 18. stoljeća gotovo ništa. Iznimku čine oltari u crkvi svete Marije u Glavotoku. Tako se doznaje da je onaj s lijeve strane posvećen svetom Antunu Padovanskom podigao venecijanski altarist Giuseppe Bisson. On je oltar ugovorio 1758., a dovršio 1760. za cijenu od 503 dukata i stotinu svetih misa po vlastitoj nakani. Iste je 1758. ugovoreno i podizanje nasuprotnog oltara u čast svetog Jakova, a za što su Bissonu isplaćena 503 dukata i baril vina nakon dovršetka njegove gradnje 1761. godine. ${ }^{1} \mathrm{U}$ istoj je crkvi mramorni anđeoski par,

IVANČIĆ 1910: 220; BOLONIĆ I ŽIC-ROKOV 1977: 356; RUNJE 2005: 108, 110. 
postavljen nad bočna vrata uz glavni oltar, prepoznat kao djelo venecijanskog kipara Giuseppea Bernardija (Pagnano, 1696. - Venecija, 1774.), i datiran u šesto desetljeće 18. stoljeća. ${ }^{2}$

Može se utvrditi kako se u spomenutim samostanima na Krku i Cresu najraniji sačuvani mramorni oltar nalazi u crkvi svetog Franje u gradu Krku. No, potrebno je istaknuti kako su krčki samostan i crkvu franjevci trećoreci preuzeli tek 1783. od ranijih vlasnika, franjevaca konventualaca. Oni su neposredno prije spomenute godine napustili samostan zbog pomanjkanja redovnika, a trećoreci su se $\mathrm{u}$ njega uselili dopuštenjem dužda Paola Reniera. ${ }^{3}$ Krčki je oltar posvećen svetom Antunu Padovanskom te se nalazi kao prvi s desne strane jednobrodne crkve. Za njegovu gradnju gvardijan fra Ivan (Zuanne) Cicuta platio je 23. prosinca 1708. iznos od 400 zlatnika neimenovanom majstoru. ${ }^{4}$ Na poticaj gvardijana fra Feliksa Bartolija 1741. krčka je općina izabrala svetog Antuna za zaštitnika grada. Stoga je na svečev blagdan katedralni kaptol služio misu na njegovu mramornom oltaru, nakon koje je uslijedila procesija krčkim ulicama. No, već 1743. došlo je do spora između kaptola i franjevaca pa se otada ophod održavao samo u samostanskom klaustru. ${ }^{5}$ Oltarna pala prikazuje viziju svetog Antuna Padovanskog, odnosno klečećeg sveca kako ljubi nogu malenom Djetetu Isusu, a koji mu se ukazuje na oblaku okružen anđelima. Pala se dovodi u vezu s majstorom nazvanim slikar „Ekstaze sv. Augustina“, koji je djelovao u Rijeci i Krku u prvim desetljećima 18. stoljeća. ${ }^{6}$ Valja upozoriti kako je na pali prikazan i anđeo koji nosi prelatski grb. On je identificiran s onim krčkog biskupa Baldassarea Nossadinija, rođenog 1648. u Veneciji, koji je službu otočkog ordinarija obnašao između 1688. i 1712. godine.?

Podaci o vremenu nastanka i cijeni oltara crpljeni su iz rukopisne zbirke krčkoga gvardijana Feliksa Bartolija, koja se čuva u samostanskom arhivu. ${ }^{8} \mathrm{U}$ ovom se izvoru spominje i ime njegova autora, arhitekta Giuseppea Cavallierija. ${ }^{9}$ Da je oltar

2 TOMIĆ 2005-2007: 372-374.

3 IVANČIĆ 1910: 228.

4 Isto.

5 Isto: 229.

6 BRALIĆ 2012: 229.

7 Identifikaciju grba izvršila je Nina Kudiš u izlaganju pod nazivom „Slikarstvo 17. i 18. stoljeća u samostanima franjevaca trećoredaca na Krku i Cresu“, održanom na međunarodnom znanstvenom skupu Trećoredska glagoljaška tradicija u europskom kontekstu, Zagreb, 28. rujna 2013.

8 Bartolijev zbornik nastao je između 1741. i 1743. godine, a puni mu navod glasi: Collectanea Bartoliana a Croatis Bartolijev Zbornik dicta, ab Auctore Patre Magistro Fratre Felice M. a Bartoli Veglensi, Ord. is Minorum Conventualium Ex-Provinciali Vegle - Krk, annis 1741 1743. Podaci o oltaru nalaze se u prvom svesku na stranicama 91 i 92.

9 GOJA 2010: 147-148. Ovaj je podatak iznio Bojan Goja, usputno spominjući prezime Cavallieri u raspravi o oltarima u crkvi svete Marije u Pašmanu, a u sklopu disertacije vezane uz mramorne 
doista nastao 1708., kako je zabilježeno u vrelima, potvrđuje i dosad neuočeni natpis na predeli, zaklonjen drvenim postoljem za svijećnjake. ${ }^{10}$

Oltar je podignut na dvjema stubama, sa supedanejem ukrašenim krugovima, upisanom osmerokrakom zvijezdom i rombovima. (sl. 1) Pravokutni stipes ima složen geometrijski ukras u vidu rombova s kružnim diskovima posred stranica, kao i izduženim rombovima uz krajeve. Bočno od stipesa, u drugom su planu volutne konzole koje tvore postamente koji podupiru velike spiralne volute, isklesane u kamenu i ukrašene umecima od sivog i žutog mramora. Lučna pala omeđena je okvirom s mramornim inkrustacijama, flankirana je dvama stupovima od crvenog mramora s lijepo klesanim kompozitnim kapitelima. Oni podupiru raskinuto gređe naglašenih obrata s kontinuirajućim vijencem nad palom. Bočno od stupova postavljeni su pilastri s kompozitnim polukapitelima koji se u donjem dijelu pretvaraju u velike spiralne volute. Atika se sastoji od raskinutog polukružnog zabata, u čijoj sredini dvije vitice od mesnatog lišća flankiraju konzolu sa središnjim segmentom zabata. Uz specifične bočne volute, na oltaru se javljaju i volute od mesnatog lišća unutar zabata, kao i velika kerubinska glava, jedini primjer kiparske dekoracije. Glava je tvrdo modelirana, klesana žustrim potezima dlijeta, a skicozno su naznačeni kuglasti uvojci kose, jednostavne širom otvorene oči i minijaturna krilca s jednostavno i pravilno poslaganim perima.

Ovo potvrđeno majstorovo djelo važno je kako bi se njegova djelatnost ovdje stavila u širi kontekst, odnosno kako bi se pokušalo utvrditi koja je još djela on mogao napraviti. Stilskom analizom Giuseppeu Cavallieriju se ovdje može lako pripisati gotovo identičan oltar na području nekadašnje Porečke biskupije. Riječ je o glavnom oltaru u crkvi svetog Silvestra Pape u Kanfanaru, a koja je građena od 1695. do 1714., kada ju je posvetio porečki biskup Antun Vaira (1712. - 1717.), kako stoji uklesano na komemorativnoj ploči s desne strane ulaza u crkvu. ${ }^{11}$ (sl. 2)

oltare na području Zadarske nadbiskupije. Arhiv franjevačkog samostana u Krku, Bartolijev zbornik, vol. 1., str. 91-92. „1708, 23 Decembre - L' Altare di S. Antonio di Padova in questa nostra chiesa fù fatto in questo Anno, e si spesero Ducati $400-(.$.$) ; Adi 23$ Decembre. Ricevo io infrascritto dal (...) dell' Altare del santo dè miracoli Antonio di Padova situato nella chiesa dè R. R. P. P: di San Francesco di questaCittà (...) Io Gioseppe Cavallieri mano propria - (...); (...) l'eretione dell'Altare di marmo nella nostra chiesa ad honore del' Santo dè miracoli Antonio di Padova giustio il disegno esibito da mistro Iseppo Cavalieri Architetto, (...).“

10 Natpis glasi: ANNO DONI / MDCCVIII.

11 Natpis na ploči glasi: ILLVSTRISSIMVS ANTISTES VAIRA HANC / ECCLESIAM CONSECRAVIT DIE / X IVNII 1714 / PAETORE IOANNE BRATI. Podaci s ploče slažu se i s navodima iz vizitacije porečkog biskupa Vicenza Marije Mazzolenija (1731. - 1741.) od 23. do 24. svibnja 1732., Poreč, Arhiv Porečko-pulske biskupije, Visit. Fol. 23 v.: „Visito tutto il corpo della Chiesa - in buon stato. Questa Chiesa parrocchiale e stata consacrata da Mons. Antonio Vaira Vesc. Di Parenzo adi 10 Giugno dell'anno 1714, come apparisce dall'iscrizione in marmo posto a latere della med. ma Chiesa vicino al altar dell Rosario.“ TULIĆ 2012:186-187. 
I u Krku i u Kanfanaru identično su riješeni stipesi i njegove bočne konzole, retabl sa širokim bočnim volutama i atika s mesnatim lisnatim viticama. Korišten je isti mramor, žuti, crni i crveni, u kombinaciji s istarskim kamenom. Jedina je razlika da su u Kanfanaru kapiteli korintski, no jednako vješto klesani kao oni kompozitni u Krku, a umjesto krčkog kerubina, u Kanfanaru je u tjemenu luka pale isklesan grb obitelji Ruffini. Štoviše, na predeli, koja je većim djelom zaklonjena kasnijim mramornim tabernakulom, može se iščitati ime donatora, podestata Victora Ruffinija i 1707. godina. ${ }^{12} \mathrm{~S}$ obzirom na kronologiju gradnje, može se smatrati da je oltar u Kanfanaru poslužio kao model za onaj u Krku. Naime, arhivski izvori spominju da je krčki oltar napravljen prema nacrtu koji je priložio upravo arhitekt Cavallieri.

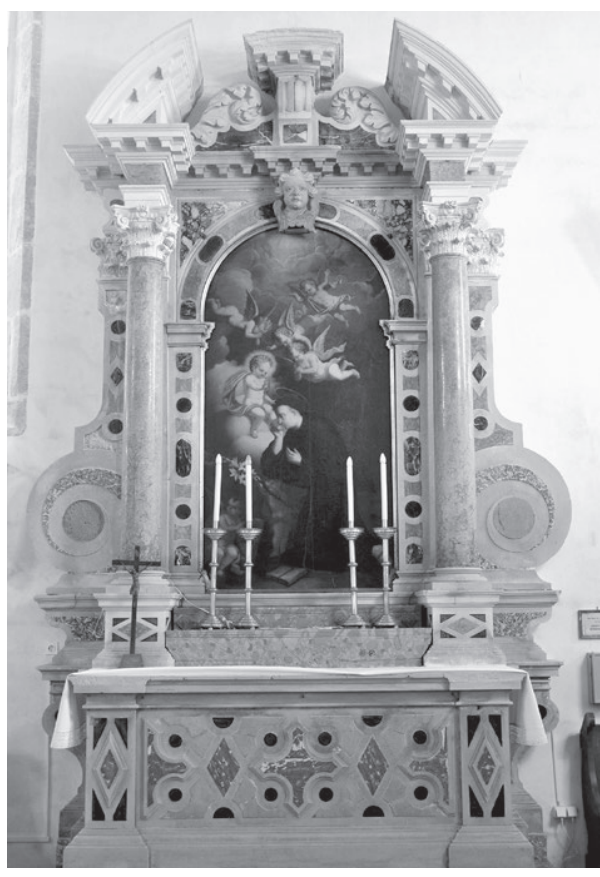

Slika 1: Giuseppe Cavallieri, oltar svetog Antuna Padovanskog, crkva svetog Franje, Krk, 1708.

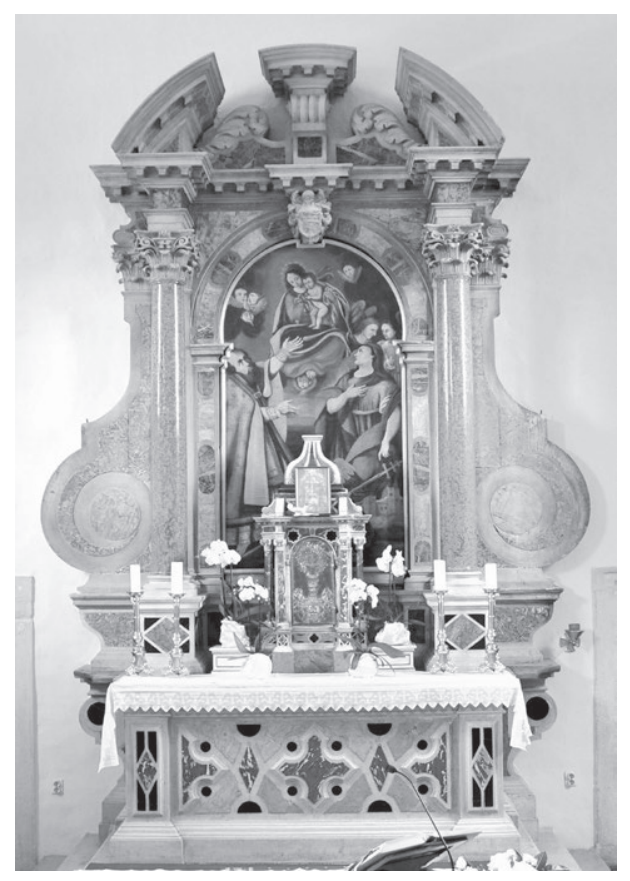

Slika 2: Giuseppe Cavallieri, glavni oltar, župna crkva svetog Silvestra Pape, Kanfanar, 1707.

Analiza Cavallierijevih oltara ukazuje na to da je majstor poznavao uobičajene arhitektonske sheme venecijanskih slavolučnih oltara 17. stoljeća, na prvome mjestu Baldassarea Longhene, Giuseppea Sardija ili Alessandra i Paola Tremignona. No, stroge te, u tektonskom i dekorativnom smislu, klasične venecijanske oltare,

12 Natpis glasi: VICTORIS RVFFINI / PRAET. VIGILANTIA / ANNO 1707. Isti se podestat 1722. spominje na natpisu uklesanom na stipes glavnog oltara u crkvi svetog Petra u nedalekom mjestu Baratu. Taj natpis glasi: SVB REGIMINE ILLMI. DNI. VICTORIS RVFFINI / ANNO DNI. MDCXXII. 
Cavallieri je prilagodio periferiji udaljenoj od jačeg umjetničkog centra. Mesnate lisnate vitice na zabatima, kao i s vanjskih strana stupova retabla oznaka su odstupanja od strogih arhitektonskih pravila u korist dekorativnosti, koja je oduvijek bila draga estetski manje zahtjevnim naručiteljima. No, Cavallierijeva važnost leži u tome što su njegovi oltari od kamena s mnoštvom mramornih dijelova bili početak u opremanju crkava suvremenim umjetničkim namještajem po ukusu 18. stoljeća. Stoga je njegova uloga bila iznimna u zamjeni starijih drvenih pozlaćenih i polikromiranih oltara novima od skupljeg i trajnijeg materijala.

Krčki i kanfanarski oltar mogu okvirno biti vodilje i prilikom atributivnog rješavanja nekoliko sličnih oltara iz prvog desetljeća u Istri, ali i na otoku Krku. Najstariji godinom datirani mramorni oltar 18. stoljeća u središnjoj Istri nalazimo u župnoj crkvi u Žminju. Riječ je o drugom desnom oltaru posvećenom Gospi od Ružarija, a 1704. dali su ga podignuti žminjski župnik i kanonik Santo Rovis te gastald bratovštine Giovanni Rovis. ${ }^{13}$ Taj slavolučni oltar ima jednako ukrašen supedanej kao Cavallierijev krčki oltar, a način klesanja korintskih kapitela istovjetan je onima u Kanfanaru. Žminjski oltar ima i prepoznatljivu skicozno klesanu kerubinsku glavu, postavljenu među lisnate volute isklesane na jednak način kao i u Kanfanaru i Krku. I nasuprotni oltar Svih Svetih, proviđen godinom 1707., djelo je istog majstora. Najmonumentalniji je istarski oltar koji se može pripisati Giuseppeu Cavallieriju onaj glavni, također u Žminju. (sl. 3) Podignuo ga je kanonik Santo Rovis 1706. godine. ${ }^{14}$ Oltar ima četiri monumentalna korintska stupa, čiji su kapiteli vješto izvedeni s nazubljenim lišćem te obilnom upotrebom svrdla. Jednaki se senzibilitet može primijetiti i na identično isklesanim kompozitnim kapitelima u Krku. Ondje je ponovljen i karakteristični kerubin u tjemenu luka oltarne pale, kao i u Krku te grb pod vizirom okružen mesnatim listovima poput onog u Kanfanaru. Uz radionicu Giuseppea Cavallierija može se povezati još desetak oltara u istarskim župnim crkvama. To su: glavni oltar u Lindaru (1717.) i Pazinskim Novakima, treći lijevi oltar (1714.) i krstionički oltar (1710.) u župnoj crkvi u Žminju, potom glavni oltar u crkvi svetog Barnabe u Vižinadi, glavni oltar iz 1714. u rovinjskoj crkvi Gospe od Milosti, glavni oltar u župnoj crkvi u Šumberu (1717.), desni bočni oltar u župnoj crkvi u Čepiću (1707.) te glavni oltar u crkvi svete Marije na Škrilinah (1707.). Od spomenutih se oltara, šiljatim oblikom zaključka oltarne pale, nad kojom počivaju velike lisnate vitice i kerubinska glava, ističe glavni oltar u crkvi svetih Kuzme i Damjana u Grožnjanu. Taj je oltar dao podignuti grožnjanski župnik Antonio Puzzer 1706. godine, kako se može zaključiti iz grba s inicijalima na stipesu. ${ }^{15}$

\footnotetext{
13 Natpis na predeli glasi: CVRA R. D. SANCTI / ROVIS, CAN.ci SVB GAS. D. IOANNE ROVIS, EREXIT / ANO. DNI. MDCCIIII.. TULIĆ 2012:187.

14 Natpis se nalazi u kartuši pod zabatom: VIGILATIA / SANCTI ROVIS / CAN.i AC PLEB. / FECIT. Na vrhu oltara među lisnatim viticama uklesan je natpis: M. D. CC VI.

15 RADOSSI 1987-1988: 228.
} 
Oltari Cavallierijeve radionice, kao i inačice koje su iz nje izašle, postali su prepoznatljivi ne samo u Istri već i na otoku Krku. Takav je slučaj oltara Gospe od Ružarija u crkvi svetog Apolinara u Bogovićima, a koji se ovdje također može pripisati Cavallieriju. (sl. 4) Oltar je podignut 1709. za uprave Zuannea Balbija. ${ }^{16}$ Zamišljen je poput slavoluka s četirima stupovima, dvjema nišama za kipove u interkolumniju i središnjom lučnom palom. Nad prekinutim gređem $\mathrm{s}$ kontinuirajućim vijencem i naglašenim obratima smješten je segmentni polukružni zabat, a nad njime istaci s mesnatim viticama i središnjim postamentom, također ukrašenim viticama. Cavallieri se za retabl oltara mogao ugledati na onaj glavni u venecijanskoj crkvi San Zulian, koji je podigao Giuseppe Sardi u sedmom desetljeću 17. stoljeća, a skulpturama u interkolumniju ukrasio Antonio Raffaelli. ${ }^{17}$ U krčkom slučaju preuzeta je samo idejna shema, dok su kipovi na atici najvjerojatnije postavljeni naknadno. Ove se kvalitetne skulpture svetog Dominika i svetog Antuna Padovanskog mogu pripisati radionici poznatog venecijanskog kipara Paola Callala (Venecija, 1655. - 1725.).

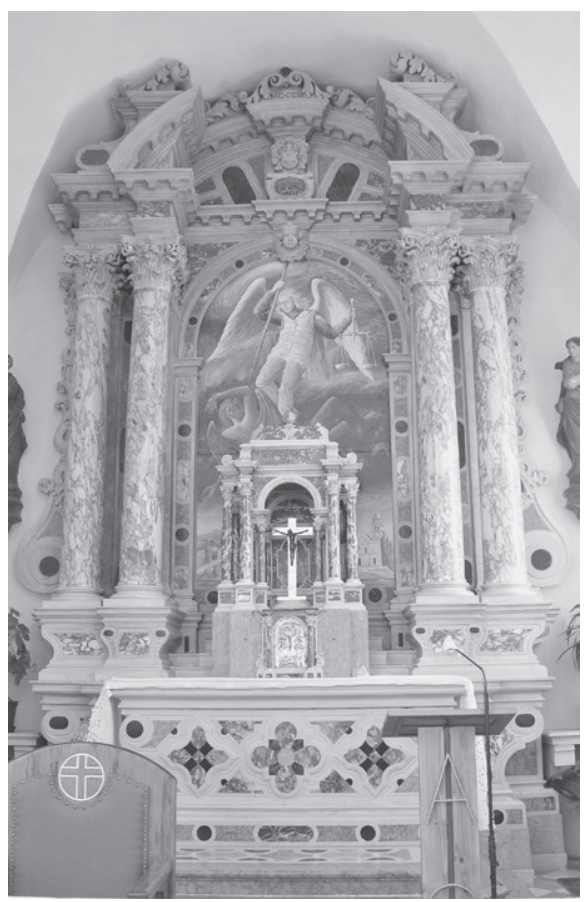

Slika 3: Giuseppe Cavallieri, glavni oltar, župna crkva svetog Mihovila, Žminj, 1706.

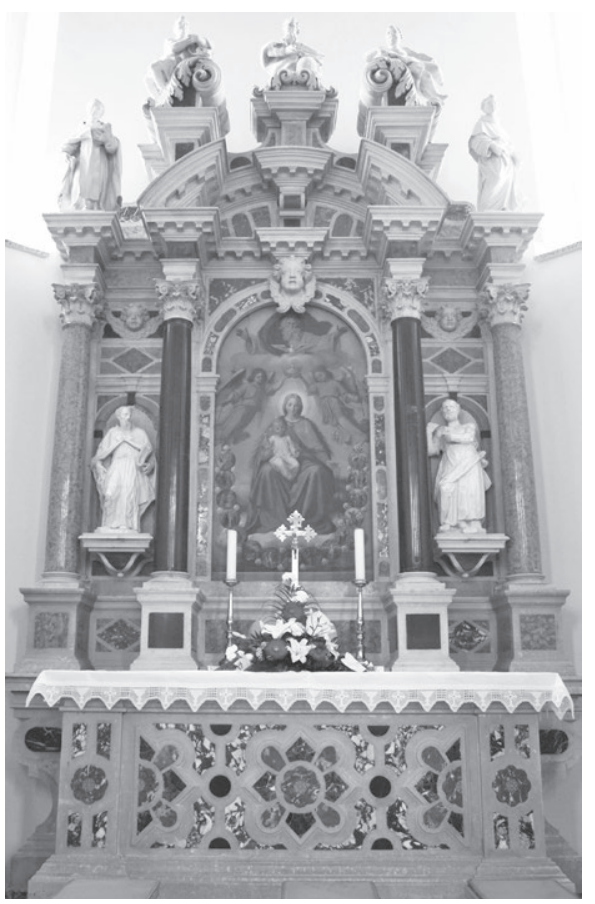

Slika 4: Giuseppe Cavallieri, oltar Gospe od Ružarija, župna crkva svetog Apolinara, Bogovići, 1709.

$\overline{16}$ DUJMOVIĆ I GALOVIĆ 2008: 61. Natpis uklesan na predeli glasi: FV ERETO SOTO IL REG.TO / DEL N: II: SIG: ZVANNE / BALABI PROVED.E / ANNO DNI 1709. 
U drugoj četvrtini 18. stoljeća mramorni su oltari podignuti i u drugim trećoredskim crkvama na Krku i Cresu. Tako je u crkvi svete Marije Magdalene u Portu sagrađen glavni oltar, odnosno njegov kameni stipes ukrašen uz rubove glavama kerubina s bokorom cvijeća te mramornom skulpturom titularne svetice u sredini. Oltar je 1730. dao podignuti gvardijan fra Petar Vidinić, a sljedeće ga je godine posvetio krčki biskup Giovanni Federico Orsini Rosa. ${ }^{18}$ Između 1745. i 1749. nabavljen je i mramorni tabernakul glavnog oltara. On se izričito navodi u popisu crkvenog inventara, koji je potonje godine napravio gvardijan fra Antun Petrelin. ${ }^{19}$ I dok su se gvardijani prilikom nabave glavnog oltara i tabernakula obratili venecijanskim altaristima, za istovremeni mramorni bočni oltar svetog Nikole majstora su našli u nedalekoj Rijeci. On se može pripisati riječkom altaristu i kiparu Antoniju Michelazziju (Gradisca d'Isonzo, 1707. - Rijeka, 1771.), odnosno njegovoj radionici. ${ }^{20}$ (sl. 5) Stipes oltara ukrašen je pravokutnim poljem od crvenog mramora, u čijem je središtu kružni reljef od oblaka s dvama kerubinima. Bočno od stipesa smješteni su postamenti za vanjske stupove retabla. Oni su zarotirani pod kutom od četrdeset i pet stupnjeva u odnosu na stipes, a istu liniju prate i postamenti za bočne kipove. Slavolučni retabl sastoji se od središnje niše za kip svetog Nikole, a flankiraju je dva para korintskih stupova, postavljenih nad zarotirane baze. Stupovi nose gređe koje prati izlomljenu liniju retabla. Atičko polje u obliku peterokuta bočnih konkavnih stranica ukrašeno je mramornim ovalom te flankirano segmentima raskinutog polukružnog zabata. Kiparski ukras uz središnji lik svetog Nikole upotpunjuju kipovi svetog Franje s lijeve te svetog Antuna Padovanskog s desne strane, kao i dva para putta na atici. Može se utvrditi kako je direktni predložak oltaru iz Porta bio onaj bočni posvećen svetom Franji Ksaverskom, podignut u katedrali u Senju. (sl. 6) Taj je oltar Michelazzi sagradio 1738., a donirao ga je senjski plemić Stjepan Udragović. ${ }^{21}$ U obama su slučajevima gotovo svi arhitektonski dijelovi oltara jednako definirani, od oblika stipesa, rotacije stupova, artikulacije gređa te atičkog polja. Valja naglasiti da je senjski oltar nešto raskošniji po vrsti mramora te superiorniji kada je riječ o kiparskoj opremi. Od skulptura u Portu najuspjelija je ona središnja svetog Nikole. Dostojanstveni lik sveca s jednostavno isklesanom draperijom pluvijala bez jačih

17 ROSSI 2003: 27-34.

18 BADURINA 1980: 16, 30; CIKOVIĆ 2016: 121. Natpis o donatoru oltara uklesan je pod rub menze i glasi: P: PIETRO VIDINICH FECE FARE DEL PROPIO A. D. M. D. C. C. XXX. Komemorativni natpis o posveti oltara danas se čuva u samostanskoj zbirci te glasi: ALTARE HOC CONSE / CRAT. FVIT DIE XXVI / NOV.ERIS MDCCXXXI / AB ILL.MO ET R.MO / D. D. I. F. ORSINI VEGLEN. / EPIS.PVS.

19 BADURINA 2013: 52; CIKOVIĆ 2016: 124.

20 TULIĆ 2012: 248-249; ŠOUREK 2015: 186. Spomenuti sam oltar radionici Antonija Michelazzija usputno pripisao 2012., no bez popratne rasprave.

21 LOKMER 2006: 141-146. 
kjaroskuralnih odnosa najbliži je Michelazzijevu liku starozavjetnog svećenika na reljefu zaruka Marije i Josipa s atike oltara svetog Josipa iz 1733. - 1734. u nekadašnjoj isusovačkoj crkvi svetog Vida, današnjoj riječkoj katedrali. ${ }^{22}$ Blizak mu je i lik svetog Nicefora Biskupa, postavljen s lijeve strane Michelazzijeva glavnog oltara, podignutog 1735. u nekadašnjoj katedrali u Pićnu. ${ }^{23}$ Bočne skulpture oltara u Portu slabije su kvalitete te su najvjerojatnije djelo nekog Michelazzijeva suradnika ili pomoćnika u radionici.

U drugoj četvrtini 18. stoljeća nastao je i jednostavni glavni oltar u skromnoj samostanskoj crkvi svetog Jeronima u Martinšćici na Cresu. Pravokutni stipes od kararskog mramora ukrašen je dvama kvadrilobama od crvenog francuskog mramora, a u središnjem ovalnom polju od crnog mramora postavljen je duboki reljef s prikazom svetog Jeronima. (sl. 7) Ta malena, no vrlo kvalitetna mramorna skulptura prikazuje stojeći i obnaženi lik sveca, koji je oko bokova ogrnut draperijom. Svetac u spuštenoj ljevici drži zatvorenu knjigu, a desnicom se udara u prsa. Da bi se ovoj skulptorskoj minijaturi dao što jači plasticitet, vješti je kipar sveca smjestio ispred visokog panja o kojeg je ovješen kardinalski šešir. Uz Jerolimove noge, s lijeve je strane prikazan lav. Ta mramorna skulptura iz Martinšćice, tipično za posttridentsku umjetnost, spaja dva ikonografska obrasca prikazivanja svetog Jeronima. ${ }^{24}$ Knjiga i kardinalski šešir znak su Jeronima kao crkvenog naučitelja, kako ga prikazuje i slika Baldassarea D'Anne iz 1636., postavljena upravo nad ovim mramornim oltarom. ${ }^{25}$ Obnaženi lik koji se udara kamenom o prsa te panj i lav u pozadini predstavljaju svetog Jerolima u ulozi pokajnika, povučenog u isposnički život. Međutim, od ikonografije je mnogo važnije utvrditi i predložak za ovu vrlo kvalitetnu skulpturu iz Martinšćice. On se može prepoznati u čuvenom svečevu kipu što ga je za oltar prokuratura Girolama Zanea u venecijanskoj crkvi Santa Maria Gloriosa dei Frari isklesao kipar Alessandro Vittoria (Trento, 1525. Venecija, 1608.). (sl. 8) Skulptura iz crkve dei Frari nastala je u razdoblju između 1566. i 1575.,a zbog uspješne kompozicije te prirodnosti muskulature i staračkog izraza lica bila je poznata i često kopirana. ${ }^{26}$ Primjerice, nešto slobodniju varijantu Vittorijina kipa oko 1688. izveo je Paul Strudel u svom liku svetog Jerolima na oltaru obitelji Giustachini u padovanskoj crkvi Santa Maria del Carmine. ${ }^{27}$ Majstor creskog svetog Jeronima svakako je poznavao slavni uzor iz Frara. Može se pretpostaviti da je autor skulpture iz Martinšćice djelovao u Veneciji u drugoj četvrtini 18. stoljeća, odnosno u vremenu kada se ponovno tražilo uzore u skulpturi velikana kasnog 16. stoljeća, a kakav je bez dvojbe bio upravo Alessandro Vittoria.

22 MATEJČIĆ $1967-1968: 158$.

23 MATEJČIĆ 1978: 163; TULIĆ 2012: 248.

24 GRGIĆ 1990: 297-299.

25 FUČIĆ 1949: 61; Isti 1995: 93.

26 LEITHE-JASPER 1999: 26-29; BACCHI 2000: 802. 


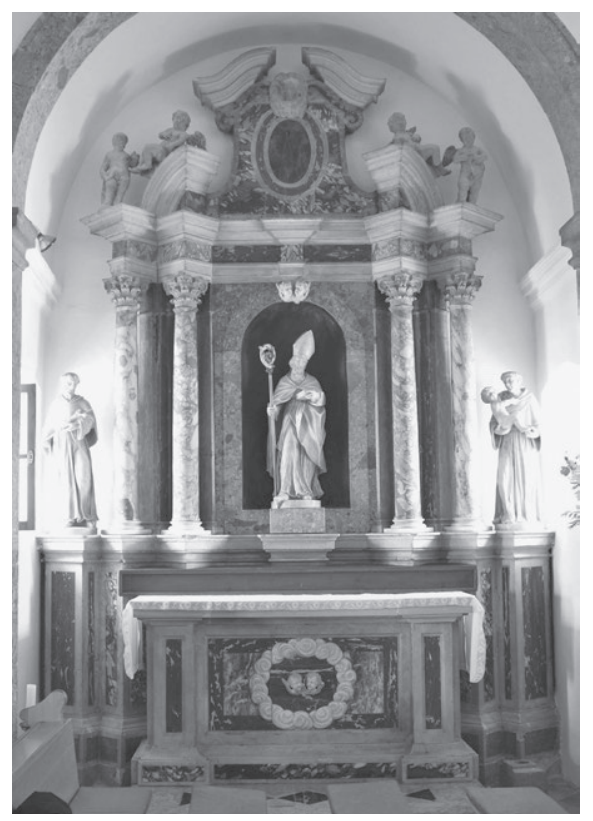

Slika 5: Antonio Michelazzi, oltar svetog Nikole, crkva svete Marije Magdalene, Porat

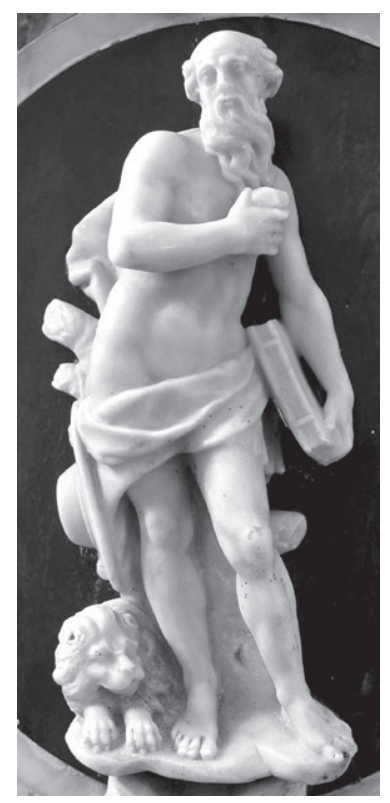

Slika 7: Venecijanski kipar, sveti Jerolim, crkva svetog Jerolima, Martinšćica

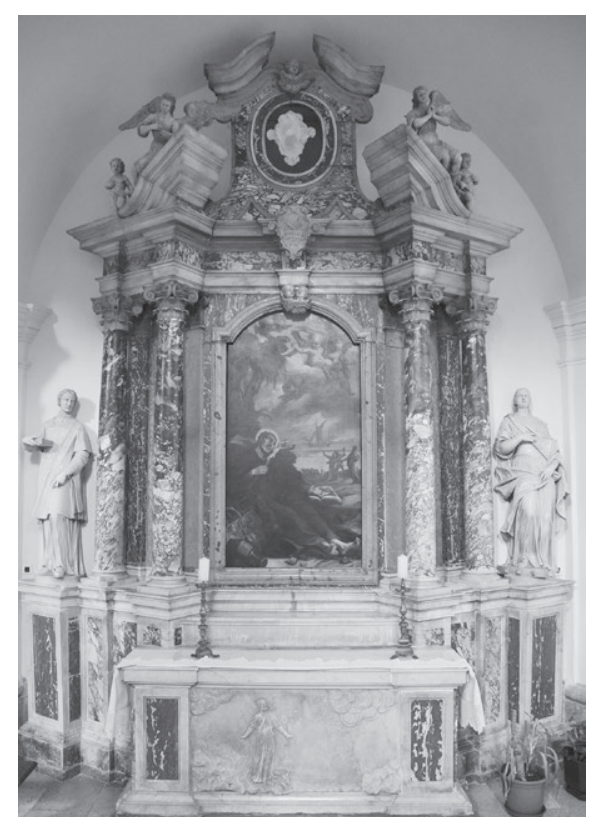

Slika 6: Antonio Michelazzi, oltar svetog Franje Ksaverskog, Katedrala, Senj, 1738.

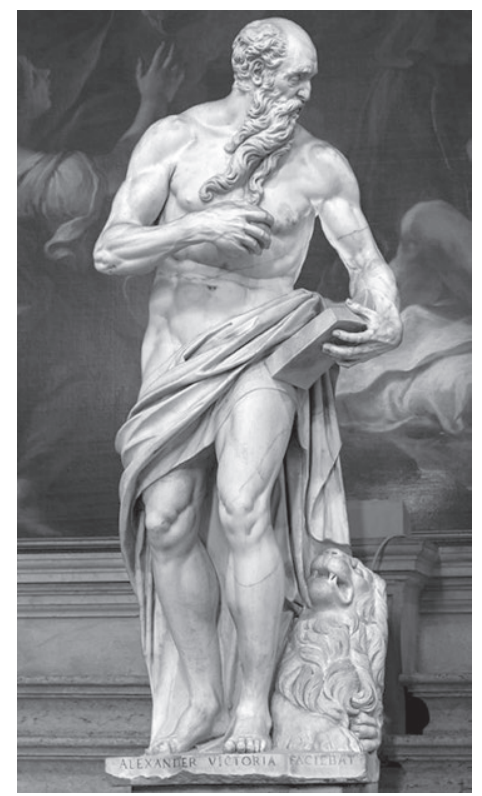

Slika 8: Alessandro Vittoria, sveti Jerolim, Santa Maria Gloriosa dei Frari, Venecija, 1566. - 1575. 
Konačno, prilog o mramornim oltarima kod kvarnerskih trećoredaca valja zaključiti neobjavljenim glavnim oltarom nekadašnje samostanske crkve svetog Nikole u Porozini na Cresu. (sl. 9) Redovnici su u 16. stoljeću preuzeli stariju gotičku crkvu iz 15. stoljeća, a opsluživali su je sve do ukinuća samostana 1843., koji je danas ruševina. ${ }^{28}$ Sredinom 18 . stoljeća redovnici su poduzeli značajan zahvat: gradnju novoga glavnog oltara. On je uzdignut na dvjema stubama, a supedanej mu je ukrašen pločom od žutog mramora s dvama upisanim krugovima i četverolistom. Pravokutni stipes uz krajeve ima dva kerubina s bokorom cvijeća, koji danas nedostaju, dok je u središnjoj lisnatoj kartuši reljefna figura s prikazom svetog Nikole. Na predeli je postavljeno mramorno svetohranište u obliku edikule zaključene lukom. Ono tvori postolje za središnji mramorni kip svetog Nikole u biskupskom ornatu. Na postamentu je slijeva kip svetog Franje Asiškog, a zdesna svetog Ivana Krstitelja. Oltar ima i bočna ophodna vrata na čijim su vrhovima dva poklekla mramorna putta. Te su dvije spretno klesane skulpture i kiparski najkvalitetnije izrađeni kipovi oltarne cjeline. Svi su kipovi obrađeni i sa stražnje strane jer su bili vidljivi i iz malenog redovničkog kora iza oltara. Oltar je datiran u godinu 1747. natpisom uklesanim na stražnju stranu oltarnih ophoda. ${ }^{29}$ Porozinski je oltar svojom tipologijom jedinstven unutar onih podignutih u trećoredskim crkvama na Kvarneru te je jedini koji ima tri svetačka kipa umjesto slavolučnog retabla s oltarnom palom ili nišom za skulpturu. Takvi su oltari bili uobičajeni za malene oratorije i privatne kapele ladanjskih vila po Venetu i Furlaniji. Odabir takve tipologije zacijelo je uvjetovan i relativno niskim svodom porozinske crkve te je bio kudikamo prikladniji od vertikalnog arhitektonskog retabla. Zasad se ne može pouzdanije govoriti o autoru kiparske dekoracije. Pojedine skulpture, poput putta ili svetog Ivana Krstitelja, pokazuju određene sličnosti s padovanskom skulpturom sredine Settecenta. Može se tek pretpostaviti da je autor mogao potjecati iz šireg kruga kipara oko Antonija Bonazze (Padova, 1698. - 1763.) ili Francesca Rizzija (Veggiano, 1729. - 1793.).

Ista radionica koja je izvela glavni oltar napravila je i mramorne stipese dvaju bočnih oltara. I dok je onaj s lijeve strane, posvećen svetoj Katarini Aleksandrijskoj, izgubio svoj mramorni figuralni ukras, onome s desne sačuvana je mramorna figura s prikazom titulara svetog Antuna Padovanskog. Oba oltara zadržala su starije drvene retable, koji su višekratno preslikani. Njihov izgled u obliku edikule s jonskim stupovima i palom koja seže do pod vrh trokutnog zabata govori u prilog dataciji u drugu četvrtinu ili sredinu 17. stoljeća. S time se slaže i oltarna

27 DE VINCENTI I GUERRIERO 2003: 405, 407.

28 FUČIĆ 1995: 10.

29 Natpis glasi: ANNO D: / 1747. 


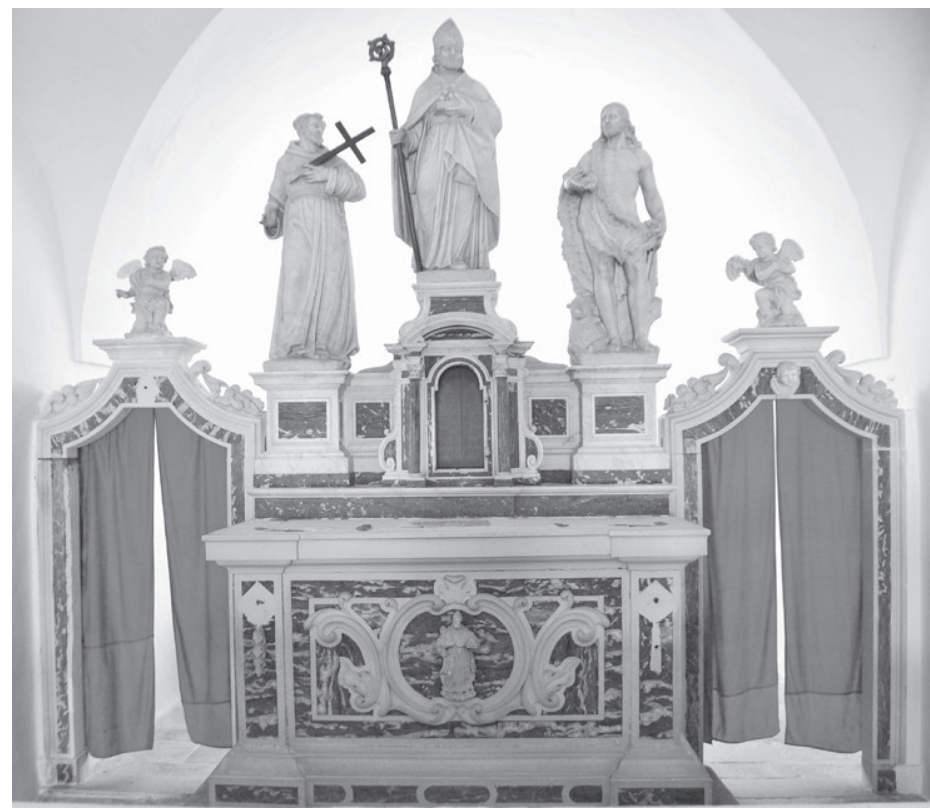

Slika 9: Glavni oltar s kipovima svetog Franje, Nikole i Ivana Krstitelja, crkva svetog Nikole, Porozina, 1747.

slika s prikazom Bogorodice i svetog Antuna Padovanskog iz radionice slikara Baldassarea D’Anne (oko 1572. - 1646.), djelatnog u Veneciji. ${ }^{30}$

Može se zaključiti kako samostani franjevaca trećoredaca na Krku i Cresu ne obiluju mnoštvom vrhunskih altarističkih i kiparskih ostvarenja u skupocjenom mramoru. No, bez dopuna dosad skromne istraženosti inventara njihovih samostana i crkava bilo bi mnogo nezahvalnije govoriti o ukupnoj umjetničkoj baštini koju su redovnici stoljećima s mnogo pažnje, odricanja i ljubavi marljivo skupljali. Ovdje kontekstualiziran oltar Giuseppea Cavallierija iz krčkog samostana ključan je za identifikaciju čitavog niza sličnih oltara koji mu se mogu pripisati u Istri i na Krku. Oltar radionice Antonija Michelazzija u Portu iznova potvrđuje kako je Rijeka u 18. stoljeću bila nezaobilazno mjesto

30 BRALIĆ 2012: 19. Kada je riječ o slikaru Baldassareu D'Anni, onda njemu treba pripisati još nekoliko djela. Po kvaliteti, na prvom je mjestu slika Poklonstva pastira iz samostana svetog Antuna Opata u Rabu te sliku Sveti Jeronim pokajnik iz zbirke franjevačkog samostana u Makarskoj. D'Anninoj radionici treba pribrojiti i oltarnu palu Gospa Karmelska sa svetim Šimunom Stockom, svetim Rokom i Ivanom Krstiteljem te dušama u čistilištu u župnoj crkvi u Belom na Cresu, velikim djelom preslikanu Posljednju večeru u blagovaonici franjevačkog samostana u Kamporu na Rabu, kao i sliku Bogorodica sa svetim Ivanom Krstiteljem i svetim Rokom što se časti u svetištu Gospe od Komušine-Konđila u Bosni i Hercegovini. Spomenute slike dio su studije o slikaru koju pripremaju autor ovog priloga i Nina Kudiš. 
za nabavu mramornih oltara i skulpture, po čemu joj pripada posebno mjesto među gradovima na istočnoj jadranskoj obali. Na dugo trajanje vrhunskih venecijanskih predložaka upućuje vrlo kvalitetni lik svetog Jerolima, izrađen na stipesu glavnog oltara u Martinšćici. Konačno, tipološki jedinstven glavni oltar u Porozini pokazuje kako su trećoreci nabavili raskošnu i modernu mramornu cjelinu, koja je njihovoj malenoj i skromnoj crkvi dala prividan sjaj mnogo većih i važnijih baroknih građevina.

\section{Bibliografija}

BACCHI, Andrea. 2000. Alessandro Vittoria. U La scultura a Venezia da Sansovino a Canova, ur. Andrea Bacchi, 800-805. Milano: Longanesi \& Co.

BADURINA, Anđelko. 1980. Porat - Samostan franjevaca trećoredaca 1480-1980. Zagreb: Provincijalat franjevaca trećoredaca.

BADURINA, Anđelko. 2013. Inventar samostana sv. Marije Magdalene u Portu na otoku Krku (1734.-1878.). Rijeka-Zagreb: Glosa d. o. o. Rijeka.

BOLONIĆ, Mihovil, Ivan ŽIC-ROKOV. 1977. Otok Krk kroz vjekove. Zagreb: Kršćanska sadašnjost.

BRALIĆ, Višnja. 2012. Barokno slikarstvo u sjevernojadranskoj Hrvatskoj - slikari, radionice $i$ utjecaji. Doktorska disertacija, Filozofski fakultet Sveučilišta u Zagrebu.

CIKOVIĆ, Danijel. Doprinos Artura Schneidera inventarizaciji hrvatske umjetničke baštine - nekoliko krčkih primjera osamdeset godina kasnije. Hrvatski povjesničari umjetnosti, Zbornik radova posvećen Arthuru Schneideru 1879. - 1946. (u tisku).

DE VINCENTI, Monica, Simone GUERRIERO. 2003. Scultori trentini a Venezia. Scultori veneziani a Trento. U Scultura in Trentino, Il Seicento e il Settecento I, ur. Andrea Bacchi, Luciana Giacomelli Bacchi, 402-409. Trento: Provincia Autonoma di Trento, Università di Trento.

DUJMOVIĆ, Perica, Tomislav GALOVIĆ. 2008. Plovanska crikva svetoga Apolinara: 150 godina dubašljanske župne crkve u Bogovićima, 1857. -2007. Malinska: Općina Malinska - Dubašnica.

FUČIĆ, Branko. 1949. Izvještaj o putu po otocima Cresu i Lošinju. Ljetopis Jugoslavenske akademije znanosti i umjetnosti za godine 1946. - 1948. 55: 31-76.

FUČIĆ, Branko. 1995. Apsyrtides, Kulturno povijesni putopis po otočju Cresa i Lošinja. Mali Lošinj: Turistička zajednica Cres, Turistička zajednica Mali Lošinj.

GOJA, Bojan. 2010. Mramorna oltaristika u 17. i 18. stoljeću na području Zadarske nadbiskupije. Doktorska disertacija, Filozofski fakultet Sveučilišta u Zagrebu.

GRGIĆ, Marijan. 1990. Sveti Jeronim. U Leksikon ikonografije, liturgike i simbolike zapadnog kršćanstva, ur. Anđelko Badurina, 297-299. Zagreb: Kršćanska sadašnjost.

IVANČIĆ, Stjepan. 1910. Povjesne crte o samostanskom III Redu sv. O. Franje po Dalmaciji, Kvarneru i Istri i poraba glagoljice u istoj redodržavi. Zadar: tiskara E. Vitalini. 
LEITHE-JASPER, Manfred. 1999. Alessandro Vittoria e la scultura del suo tempo a Venezia. U La bellissima maniera Alessandro Vittoria e la scultura veneta del Cinquecento, ur. Andrea Bacchi, Lia Camerlengo,Manfred Leithe-Jasper, 14-45.Trento: Provincia Autonoma di Trento.

LOKMER, Juraj. 2006. Barokni oltari i druga kamena oprema katedrale Uznesenja Blažene Djevice Marije u Senju. Senjski zbornik 33: 133-192.

MATEJČIĆ, Radmila. 1978. Udio goričkih i furlanskih majstora u baroknoj umjetnosti Rijeke. Zbornik za likovne umetnosti 14: 153-174.

ŠOUREK, Danko. 2015. Altarističke radionice na granici: Barokni mramorni oltari u Rijeci i Hrvatskom primorju. Zagreb: Leykam International.

RADOSSI, Giovanni. 1987-1988. Stemmi di rettori e di famiglie notabili di Grisignana d'Istra. Atti Centro di Ricerche Storiche - Rovigno XVIII: 185-239.

ROSSI, Paola. 2003. L'altare maggiore della chiesa di San Giuliano, la sua decorazione scultorea e altri lavori del presbiterio (nei secoli XVII e XVIII). Venezia Arti 14: 27-34.

RUNJE, Petar. 2005. Glavotok Svetište Majke Božje. Glavotok: Samostan sv. Marije.

TOMIĆ, Radoslav. 2005-2007. Anđeli u Vodicama, Sutivanu i Glavotoku. Prilozi povijesti umjetnosti u Dalmaciji 41: 363-374.

TULIĆ, Damir. 2012. Skulptura, altaristika i liturgijska srebrnina u Pićanskoj katedrali: prilozi za Antonija Michelazzija i Gasparea Albertinija. U Pićanska biskupija i Pićanština, ur. Robert Matijašić, 241-259. Pazin: Državni arhiv u Pazinu.

TULIĆ, Damir. 2012. Kamena skulptura i oltari 17. i 18. stoljeća u Porečko-pulskoj biskupiji, Doktorska disertacija, Filozofski fakultet Sveučilišta u Zagrebu.

\section{A Contribution to the Knowledge of the 18th-century Marble Altars and Sculpture in Franciscan Tertiaries' Churches on the Islands of Krk and Cres}

During the eighteenth century, the monastery churches of Franciscan Tertiaries on the islands Krk and Cres were renovated and furnished with new furniture and fittings. The earliest marble altar erected was the one dedicated to St. Anthony of Padua in the church of St. Francis on the island of Krk. It was built by the architect Giuseppe Cavallieri in 1704, but its master builder is an almost completely unknown figure. On the basis of stylistic analysis, this paper contextualizes Cavallieri's altar, and ascribes around fifteen other altars from Istria and Krk to his workshop. In the second quarter of the eighteenth century, the main and lateral altars in honour of St. Nicholas in the church of St. Mary Magdalene in Porto were built. These altars are the work of altar builder and sculptor Antonio Michelazzi of Rijeka and his associate. A small, but a high quality sculpture of St. Jerome was made for the main altar in Martinšćica, and the famous 16th-century Venetian sculpture by Alessandro Vittoria is recognized in this paper as a model for the Matinšćica sculpture. Finally, the paper analyses the unpublished main 
altar of the church of St. Nicholas in Porozina, which is of a unique type with three marble sculptures made in 1747.

Keywords: marble altars, sculpture, $18^{\text {th }}$ century, churches of Franciscan Tertiaries, Krk, Cres.

Ključne riječi: mramorna altaristika, skulptura, 18. stoljeće, crkve franjevaca trećoredaca, Krk, Cres.

Damir Tulić

Filozofski fakultet Sveučilišta u Rijeci HR-51000 Rijeka, Sveučilišna avenija 4 damir.tulic@gmail.com 


\section{FILOZOFSKI FAKULTET SVEUČILIŠTA U ZAGREBU \\ ZAVOD ZA HRVATSKU POVIJEST \\ INSTITUTE OF CROATIAN HISTORY \\ INSTITUT FÜR KROATISCHE GESCHICHTE}

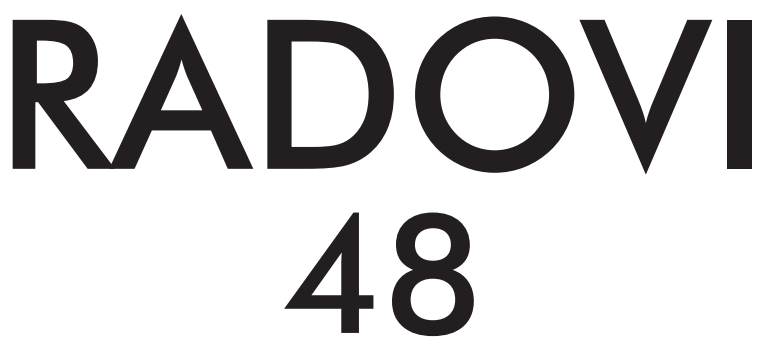

ZAVOD ZA HRVATSKU POVIJEST

FILOZOFSKOGA FAKULTETA SVEUČILIŠTA U ZAGREBU

\section{FF press}

ZAGREB 2016. 


\title{
RADOVI ZAVODA ZA HRVATSKU POVIJEST FILOZOFSKOGA FAKULTETA SVEUČILIŠTA U ZAGREBU \\ Knjiga 48
}

\author{
Izdavač / Publisher \\ Zavod za hrvatsku povijest \\ Filozofskoga fakulteta Sveučilišta u Zagrebu \\ FF-press \\ Za izdavača / For Publisher \\ Željko Holjevac \\ Glavni urednik / Editor-in-Chief \\ Hrvoje Gračanin \\ Izvršna urednica / Executive Editor \\ Inga Vilogorac Brčić \\ Uredništvo / Editorial Board
}

Bruna Kuntić-Makvić (stara povijest/ancient history), Zrinka Nikolić Jakus (srednji vijek/ medieval history), Hrvoje Petrić (rani novi vijek/early modern history), Željko Holjevac (moderna povijest/modern history), Tvrtko Jakovina (suvremena povijest/contemporary history),

Silvija Pisk (mikrohistorija i zavičajna povijest/microhistory and local history),

Zrinka Blažević (teorija i metodologija povijesti/theory and methodology of history)

Međunarodno uredničko vijeće / International Editorial Council

Denis Alimov (Sankt Peterburg), Živko Andrijašević (Nikšić), Csaba Békés (Budapest), Rajko Bratož (Ljubljana), Snježana Buzov (Columbus, Ohio), Svetlozar Eldarov (Sofija), Toni Filiposki (Skopje), Aleksandar Fotić (Beograd), Vladan Gavrilović (Novi Sad), Alojz Ivanišević (Wien),

Egidio Ivetić (Padova), Husnija Kamberović (Sarajevo), Karl Kaser (Graz),

Irina Ognyanova (Sofija), Géza Pálffy (Budapest), Ioan-Aurel Pop (Cluj),

Nade Proeva (Skopje), Alexios Savvides (Kalamata), Vlada Stanković (Beograd), Ludwig Steindorff (Kiel), Peter Štih (Ljubljana)

\section{Izvršna urednica za tuzemnu i inozemnu razmjenu / Executive Editor for Publications Exchange \\ Kristina Milković}

Tajnik uredništva / Editorial Board Assistant
Dejan Zadro

Adresa uredništva/Editorial Board address

Zavod za hrvatsku povijest, Filozofski fakultet Zagreb, Ivana Lučića 3, HR-10 000, Zagreb

Tel. ++385 (0)1 6120 150, 6120 158, faks ++385 (0)1 6156879

Časopis izlazi jedanput godišnje / The Journal is published once a year

Časopis je u digitalnom obliku dostupan na / The Journal in digital form is accessible at Portal znanstvenih časopisa Republike Hrvatske „Hrčak“ http://hrcak.srce.hr/radovi-zhp

Financijska potpora za tisak časopisa / The Journal is published with the support by

Ministarstvo znanosti, obrazovanja i športa Republike Hrvatske

Časopis je indeksiran u sljedećim bazama / The Journal is indexed in the following databases:

Directory of Open Access Journals, EBSCO, SCOPUS, ERIH PLUS, Emerging Sources Citation Index - Web of Science 


\section{Naslovna stranica}

Iva Mandić

Grafičko oblikovanje i računalni slog

Marko Maraković

\section{Lektura}

Samanta Paronić (hrvatski / Croatian)

Dražen Nemet (engleski / English)

Tisak

Tiskara Zelina d.d., Sveti Ivan Zelina

Naklada

250 primjeraka

Časopis je u digitalnom obliku dostupan na Portalu znanstvenih časopisa Republike Hrvatske ,Hrčak" http://hrcak.srce.hr/radovi-zhp

The Journal is accessible in digital form at the Hrcak - Portal of scientific journals of Croatia http://hrcak.srce.hr/radovi-zhp 


\section{RADOVI 48}

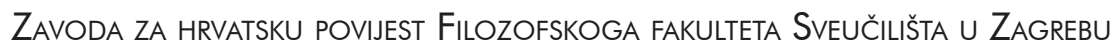

